\author{
NARTSISS SHUKURALIEVA
}

Uniwersytet Kazimierza Wielkiego

\title{
Bezpieczeństwo regionalne - integracja obronna państw Azji Centralnej
}

\section{Regional security - defense integration of the Central Asian countries}

The aim of the article is to analyse the phenomenon of security integration of Central Asian states within regional international organisations created around Russia and China. It enabled the authoritarian leaders to lower the cost of maintaining the non-democratic systems. The tactical strategies invented in one country, institutional and legal solutions and mythological constructs were also used by other participants. Moreover, they provided international infrastructure that not only gave external legitimacy to authoritarian regimes, but also served to weaken civil society and eliminate all forms of political competition. The article attempts to answer the questions of how threats were defined within regional integration structures and how international infrastructure was built to combat regional threats such as extremism, terrorism and separatism. Furthermore, preventive strategies at the institutional and legal levels are considered. Finally, the article analyses selected aspects of the so-called cultural prevention, which was intended to combat security threats and ensure regional stability.

Keywords: Central Asia, authoritarianism, security, terrorism, CIS, CSTO

Słowa kluczowe: Azja Centralna, autorytaryzm, bezpieczeństwo, terroryzm, WNP, OUBZ

\section{Wprowadzenie}

Organizacje utworzone wokół Rosji i Chin oraz szerszy kontekst międzynarodowy mają coraz większy wpływ na kwestie integracji i bezpieczeństwa regionalnego w Azji Centralnej. W praktyce mimo ambitnych celów nie przyczyniały się one do koordynacji polityk narodowych, integracji rynków czy zapewnienia bezpieczeństwa regionalnego. Organizowane w ich ramach szczyty i spotkania były raczej platformą do kontaktów i dyskusji między prezydentami i kończyły się przyjmowaniem deklaracji intencji pozbawionych 
jakichkolwiek mechanizmów implementacji ${ }^{1}$. Międzynarodowa instytucjonalizacja współpracy regionalnej dostarczała jednak szeregu innych korzyści. Po wydarzeniach kolorowych rewolucji w Gruzji, na Ukrainie i w Kirgistanie szczególnie ważne było stworzenie podstaw do solidarności politycznej między przywódcami państw członkowskich. Ponadto kontrolowane przez oba supermocarstwa organizacje regionalne dostarczały narzędzi umożliwiających uniknięcie presji ze strony Zachodu oraz promocję własnych form zarządzania politycznego i rozwoju wizji bezpieczeństwa regionalnego.

Celem niniejszego artykułu jest przedstawienie wpływu czynników zewnętrznych na procesy utrwalania i wzmacniania systemów autorytarnych. Zaprezentowano w nim zjawisko integracji obronnej państw Azji Centralnej w ramach regionalnych organizacji międzynarodowych, w których dominują Rosja i Chiny. Zastosowanie do rzeczywistości centralnoazjatyckiej ram teoretycznych zaproponowanych przez Witalija Silickiego pozwoliło na analizę działań prewencyjnych podejmowanych przez reżimy autorytarne na płaszczyźnie taktyki, instytucji oraz kultury ${ }^{2}$. Celem jest również próba odpowiedzi na następujące pytania badawcze: Jakie były podobieństwa i różnice pomiędzy promocją demokracji a promocją autorytaryzmu w państwach Azji Centralnej? Jak definiowano zagrożenia w ramach regionalnych struktur integracyjnych? Jak budowano międzynarodową infrastrukturę do zwalczania takich regionalnych zagrożeń, jak ekstremizm, terroryzm i separatyzm? Jak wdrażano strategie prewencyjne na poziomie instytucjonalno-prawnym? Jak tzw. prewencja kulturowa miała służyć zwalczaniu zagrożeń dla bezpieczeństwa i zapewnianiu stabilności regionalnej?

\section{Integracja obronna}

Wspólnota Niepodległych Państw (WNP) oraz Szanghajska Organizacja Współpracy (SOW) są głównymi organizacjami międzynarodowymi zaangażowanymi w sferze bezpieczeństwa regionalnego w Azji Centralnej. Według Nicole J. Jackson odgrywają one ważną rolę w definiowaniu zagrożeń dla Azji Centralnej, wprowadziły bowiem nowe normy wielostronnej współpracy i stworzyły nowe instytucje. Formułowane i rozwijane przez nie

1 Szerzej zob. N. Shukuralieva, Azja Centralna: uwarunkowania integracji regionalnej, [w:] Relacje Unii Europejskiej z Azja Centralna. Uwarunkowania, wyzwania, efekty, red. T. Wallas, R. Fiedler, Poznań 2018, s. 207-223.

2 V. Silitski, Contagion deterred: preemptive authoritarianism in the former Soviet Union (the case of Belarus), Stanford 2006 (CDDRL Working Papers, 66). 
modele i strategie (w tym dotyczące zarządzania państwami członkowskimi) odzwierciedlają specyfikę lokalnych autorytarnych systemów politycznych. WNP i SOW koncentrują się na ponadnarodowych kwestiach twardego bezpieczeństwa, ignorując zagadnienia bezpieczeństwa jednostki ludzkiej ( $h u$ man security). Wzmacniają zatem przede wszystkim te sektory, które służą zachowaniu status quo i zapewnieniu trwałości reżimów w państwach Azji Centralnej. W tym sensie organizacje te są platformą, za pomocą której Rosja wraz z innymi państwami członkowskimi wspierała, a czasem nawet aktywnie promowała niedemokratyczne formy rządów. Przejawiało się to zarówno na poziomie retorycznym, jak i praktycznym. Członkowie SOW zgodzili się na przykład na wzajemne konsultacje w wypadku kryzysów zagrażających pokojowi i bezpieczeństwu $\mathrm{w}$ regionie oraz na stworzenie regionalnego mechanizmu zapobiegania konfliktom. Współpraca polityczna na wysokim szczeblu była szczególnie ważna dla przywódców państw Azji Centralnej, których celem było wzmacnianie swojej wewnętrznej popularności oraz pozycji na arenie międzynarodowej ${ }^{3}$.

Integracja obronna reżimów ma utrudniać działania na rzecz ich demokratyzacji - w tym aktywność opozycji, oddolnych lokalnych ruchów społecznych czy wolność mediów - rozumiane jako rozszerzenie wpływów Zachodu w Azji Centralnej. Powyższe założenie, będące konstruktem myślenia kolonialnego (podobnie zresztą jak demokratyzacyjna misja Zachodu), pozbawiało narody tego regionu podmiotowości. Zarówno w przypadku promocji demokracji, jak i autorytaryzmu społeczeństwa Azji Centralnej były nie podmiotami, ale przedmiotami polityki - pasywnymi obiektami oddziaływania, a nie współuczestnikami działań władz. Region postrzegany był jako niezrozumiały, nieprzewidywalny i zagrażający wybuchami niepokojów społecznych. Jako źródło niestabilności na arenie międzynarodowej miał potrzebować pilnych i gruntownych zmian, a ponieważ pozbawiony był konstruktywnych pomysłów oraz niezdolny do ujarzmienia swego destrukcyjnego

3 N. J. Jackson, The role of external factors in advancing non-liberal democratic forms of political rule. A case study of Russia's influence on Central Asian regimes, „Contemporary Politics" 2010, vol. 16, No. 1, s. 113; D. Brążkiewicz, Z. Śliwa, Strategiczne interesy Rosji w Azji Centralnej, „Kwartalnik Bellona” 2011, nr 4 (667), s. 181-199; K. Żęgota, Kreowanie rzeczywistości alternatywnej. Dązenia integracyjne Rosji w przestrzeni poradzieckiej, [w:] Procesy integracyjne i dezintegracyjne na obszarze poradzieckim. Próba bilansu, red. T. Ambroziak, A. Czwołek, S. Gajewski, M. Nowak-Paralusz, Wydawnictwo „Adam Marszałek”, Toruń 2015, s. 55-70; A. Legucka, System bezpieczeństwa obszaru poradzieckiego tworzony wokót OUBZ, [w:] Bezpieczeństwo Europy. Aspekty geopolityczne, red. T.Z. Leszczyński, Polskie Towarzystwo Geopolityczne, Kraków 2015, s. 49-64. 
potencjału i samodzielnego rządzenia, miał wymagać interwencji zewnętrznej (np. Zachodu, Rosji czy Chin) ${ }^{4}$. Regionalne interesy, lokalny kontekst oraz aspiracje społeczne były więc systematycznie pomijane, a ich istotę określano za pośrednictwem angażowanej przez metropolię elity kompradorskiej. Pod tym względem promocja wartości autorytarnych opierała się na tych samych mechanizmach, co wspieranie demokracji ${ }^{5}$. Integracja obronna obejmowała więc dyfuzję autorytarnych norm, udzielanie wzajemnego wsparcia politycznego oraz współpracę na wysokim szczeblu w zakresie bezpieczeństwa. Legitymizując i wzmacniając elity rządzące, miała ona zapewnić utrzymanie status quo, a w konsekwencji wzmocnić wpływy Rosji i Chin w regionie ${ }^{6}$. Zapobiegające demokratyzacji działania prewencyjne reżimów autorytarnych można rozpatrywać w trzech wymiarach wyróżnionych przez Witalija Silickiego: taktyki, instytucji oraz kultury?

\section{Prewencja taktyczna}

Prewencja taktyczna zorientowana jest na osłabianie społeczeństwa obywatelskiego oraz systematyczne ograniczanie możliwości działania przeciwników czy wykluczanie ich ze sceny politycznej, nawet gdy nie stanowią bezpośredniego zagrożenia dla reżimu ${ }^{8}$. Na poziomie międzynarodowym infrastrukturę zapewniały WNP i SOW, systematycznie wysyłając do zrzeszonych państw przychylnych wobec władzy obserwatorów, którzy mieli śledzić odbywające się $\mathrm{w}$ nich wybory i referenda. W przeciwieństwie do opozycji oraz innych obserwatorów międzynarodowych przymykali oni oko na liczne naruszenia i uznawali głosowania za wolne, otwarte i demokratyczne, kształtując w ten sposób alternatywne standardy „wolnej i uczciwej” elekcji. W lutym 2006 r. w ramach Międzyparlamentarnego Zgromadzenia WNP utworzony został Międzynarodowy Instytut Monitorowania Rozwoju Demokracji, Parlamentaryzmu i Przestrzegania Praw Wyborczych Obywateli Państw WNP9

4 Zob. np. J. Heathershaw, D.W. Montgomery, The myth of post-Soviet Muslim radicalization in the Central Asian republics, Chatham House 2014.

5 J. Heathershaw, N. Megoran, Contesting danger. A new agenda for policy and scholarship on Central Asia, „International Affairs” 2011, nr 3 (87), s. 589-612.

$6 \quad$ N. J. Jackson, The role..., s. 112-114.

7 V. Silitski, Contagion..., s. 6-7.

8 Tamże.

9 Zatwierdzony postanowieniem Rady Międzyparlamentarnego Zgromadzenia WNP z 10.02.2006 r. nr 5: Položenie o Meždunarodnom institute monitoringa razvitiâ demokratii, parlamentarizma i soblûdeniâ izbiratel'nyh prav graždan gosudarstv učastnikov MPA SNG. 
Miał on stanowić alternatywę dla Biura Instytucji Demokratycznych i Praw Człowieka Organizacji Bezpieczeństwa i Współpracy w Europie, ale również weryfikować jego stanowisko dotyczące wyborów, przestrzegania praw człowieka oraz demokracji w regionie ${ }^{10}$. W listopadzie 2006 r. w obliczu planowanych wyborów na obszarze WNP Sekretariat SOW i Komitet Wykonawczy WNP uzgodniły zasady oficjalnej współpracy między rosyjskimi i chińskimi obserwatorami. Poprzez wspieranie wadliwie przeprowadzanych głosowań i stosunków neopatrymonialnych organizacje te pomagały Rosji legitymizować systemy polityczne w zrzeszonych krajach i tym samym wzmacniać jej oddziaływanie $\mathrm{w}$ regionie ${ }^{11}$.

Władze państw Azji Centralnej podejmowały próby eliminowania nawet biernej opozycji na emigracji, sięgając $\mathrm{w}$ tym celu po międzynarodowe instrumenty egzekucji prawa. Sprawna ekstradycja mieszkających za granicą dysydentów politycznych możliwa była dzięki regionalnym traktatom dotyczącym bezpieczeństwa ( $\mathrm{w}$ tym zwalczania terroryzmu), jak konwencja mińska z 1993 r. ${ }^{12}$ czy konwencja SOW o zwalczaniu terroryzmu z 2009 r. ${ }^{13}$ Druga $\mathrm{z}$ tych umów nadała rządom szeroki zakres uprawnień do wnioskowania o ekstradycję - wyłącznie w oparciu o oskarżenia i bez przesłuchań azylowych. Zapewniła również służbom bezpieczeństwa państw sygnatariuszy prawo do prowadzenia dochodzeń na terytorium pozostałych krajów i umożliwiła stworzenie wspólnej listy ekstremistów, terrorystów i separatystów. Nie przewidywała jednak procedur weryfikacji tego spisu ${ }^{14}$.

Według Witalija Ponomariewa ze stowarzyszenia Memoriał uzgodnienie wspólnej czarnej listy już na wstępnym etapie tworzenia międzynarodowego banku danych stało się rodzajem handlu politycznego na zasadzie:

10 W ciągu ostatnich dziesięciu lat instytut uczestniczył w pracach grup monitorujących ponad sześćdziesiąt elekcji prezydenckich i parlamentarnych, a także w szeregu referendów przeprowadzonych w krajach WNP. Szerzej zob.: A. Libman, Modeli èkonomičeskoj integracii. Mirovoj i postsovetskij opyt, IE RAS, Moskva 2009, s. 209; R. Allison, Virtual regionalism, regional structures and regime security in Central Asia, „Central Asian Survey” 2008, nr 2 (27), s. 185-202; Meždunarodnye nablûdateli partnery po razvitiû demokratii, a ne sud'i, „Sankt-Peterburgskie vedomosti”, 10.02.2016; D. Fel'dman, Političeskoe vzaimodejstvie èlit stran SNG, „Polis. Političeskie issledovaniâ" 2005, № 4, s. 89-98.

11 N. J. Jackson, The role..., s. 113.

12 Konvenciâ o pravovoj pomoŝi $i$ pravovyh otnošeniâh po graždanskim, semejnym i ugolovnym delam, Minsk 22.01.1993.

13 Konvenciâ Šanhajskoj organizacii sotrudničestva protiv terrorizma, Ekaterinburg 16.06.2009.

14 Szerzej zob. A.A. Cooley, J. Heathershaw, Dictators without borders. Power and money in Central Asia, Yale University Press 2017, s. 48. 
„wy uznajecie naszych dysydentów za terrorystów, a my uznamy za terrorystów osoby poszukiwane przez was" ${ }^{15}$. W rezultacie ogromną liczbę figurujących $\mathrm{w}$ rejestrze stanowili nie terroryści, ale niezaangażowani $\mathrm{w}$ żadne akty przemocy dysydenci polityczni bądź religijni. W 2017 r. wykaz poszukiwanych międzynarodowym listem gończym w związku z przestępstwami o charakterze terrorystycznym, separatystycznym i ekstremistycznym obejmował w ramach wspólnego banku danych o terrorystach ponad 3000 osób. We wspólnym rejestrze organizacji terrorystycznych, separatystycznych i ekstremistycznych, którym zakazano działalności na terytorium państw członkowskich SOW, widniało z kolei ponad 100 podmiotów. Było wśród nich na przykład cieszące się szerokim poparciem społecznym jedyne autentyczne ugrupowanie opozycyjne - Islamska Partia Odrodzenia Tadżykistanu. W 2015 r. zdelegalizowano ją jako organizację ,prowadzącą działania terrorystyczne"16 a jej działacze i członkowie ich rodzin poddani zostali represjom. Prokuratura Generalna Tadżykistanu wszczęła postępowanie karne przeciwko przebywającemu za granicą prezesowi partii Muchiddinowi Kabiriemu, powołując się na pięć artykułów kodeksu karnego: terroryzm (art. 179 (3)), stworzenie związku przestępczego (art. 187 (1)), nawoływanie do nienawiści na tle narodowościowym, rasowym, regionalnym (czyli w związku z pochodzeniem z pewnego regionu) lub wyznaniowym (art. 189), rebelii zbrojnej (art. 313) oraz oszustwo (art. 247). Według obrońców praw człowieka prezydent Emomali Rahmon wyeliminował w ten sposób jedyną znaczącą siłę opozycyjną, która mogła przeciwstawić się mechanizmowi sukcesji władzy w republice ${ }^{17}$.

Podobne działania państwa oraz instytucji międzynarodowych dotyczyły obywateli Uzbekistanu, gdzie o terroryzm można było oskarżyć niemal

15 Wywiad Iriny Borogan z Witalijem Ponomariewem: FSB i dviženiâ Central'noj Azii: analiz, „Agentura” [online], 18.04.2007 [dostęp: 15.03.2018], dostępny w internecie: $<$ http://www.agentura.ru/experts/ponomarev/>.

16 A. Sarkorova, V Tadžikistane zapreŝena Islamskâ̂ partiâ, „BBC Russkaâ služba” [online], 29.09.2015 [dostęp: 15.03.2018], dostępny w internecie: <http://www.bbc.com/ russian/international/2015/09/150929_tajikistan_islamic_party_ban>.

17 Tamże; FSB i dviženiâ...; V. Volkov, K čemu PIVT vynuždầt repressii so storony tadžikskih vlastej?, „Deutsche Welle” [online], 28.09.2016 [dostęp: 15.03.2018], dostępny w internecie: <http://p.dw.com/p/1K752>; PIVT vnesli v perečen' terrorističeskih organizacij RATS ŠOS, ,EurAsia Daily” [online], 4.08.2017 [dostęp: 15.03.2018], dostępny w internecie: <eadaily.com/ru/news/2017/08/04/pivt-vnesli-v-perechen-terroristicheskih-organizaciy-rats-shos>; Ob informacionnyh učetah Regional'noj antiterrorističeskoj organizacii Šanhajskoj organizacii sotrudničestva, „Regional'naâ Antiterrorističeskaâ Struktura Šanhajskoj Organizacii Sotrudničestva" [online], 28.07.2017 [dostęp: 15.03.2018], dostępny w internecie: <http://ecrats.org/ru/news/6914>. 
każdą osobę ${ }^{18}$. Zdarzało się, że nawet brak stałego meldunku muzułmanów w wieku 20-40 lat bywał powodem do podejrzeń o terminowanie w obozach terrorystycznych za granicą. Na dodatek, gdy w Rosji dochodziło do zatrzymania i ekstradycji rzekomych uzbeckich islamistów, Federalna Służba Bezpieczeństwa informowała zazwyczaj o ich domniemanym udziale w aktach terrorystycznych w Uzbekistanie, po czym w trakcie procesu sądowego zarzuty będące podstawą ekstradycji zmieniano na całkowicie inne. $\mathrm{W}$ ten sposób traktaty bezpieczeństwa regionalnego umożliwiały wydawanie i ekstradycję osób między sygnatariuszami konwencji, a wspólna walka z terroryzmem i ekstremizmem była głównie pretekstem do zwalczania przeciwników politycznych władzy w państwach Azji Centralnej ${ }^{19}$.

\section{Prewencja na poziomie instytucjonalnym}

Działania wyprzedzające na poziomie instytucjonalnym polegają na zaostrzeniu podstawowych zasad gry politycznej. Wprowadzenie zmian do konstytucji, prawa wyborczego, ustaw dotyczących funkcjonowania partii politycznych, mediów i organizacji społecznych czy kryminalizowanie niektórych rodzajów działalności obywatelskiej to kroki, które mają utrudniać potencjalne wzmocnienie opozycji ${ }^{20}$. Uchwalone w Rosji ustawy 'O zagranicznych agentach' z 2012 r. czy ‘O niepożądanych organizacjach' z 2015 r. były instrumentami umożliwiającymi zdelegalizowanie czy sparaliżowanie działań dowolnej organizacji trzeciego sektora. Oba akty prawne zatarły różnice pomiędzy organizacjami komercyjnymi i non profit (działającymi pro publico bono). Dodatkowo zawierały nieprecyzyjne, niejasne i zbyt obszerne zapisy definiujące działalność polityczną, w myśl których stawała się nią nie tylko aktywność zorientowana na zaspokajanie potrzeb obywateli, ale niemal każda forma zaangażowania społecznego ${ }^{21}$. Taka konstrukcja prawa stworzyła

18 Szerzej zob.: N. Shukuralieva, A. Lipiński, Uwarunkowania legitymizacji władzy w systemach autorytarnych. Casus państw Azji Centralnej, „Przegląd Politologiczny” 2017, nr 1, s. 196-197; ciż, Legitymizacja władzy jako wielowymiarowy mechanizm stabilizacji systemu autorytarnego. Casus państw Azji Centralnej, [w:] Azja Centralna. Tożsamość, naród, polityka, red. N. Shukuralieva, Nomos, Kraków 2018, s.15-35; N. Shukuralieva, Bezpieczeństwo międzynarodowe, terroryzm i zasoby naturalne a międzynarodowa legitymizacja władzy w krajach Azji Środkowej, „Sprawy Międzynarodowe” 2013, nr 4, s. $56-59$.

19 FSB i dviženiâ...

20 V. Silitski, Contagion..., s. 6-7.

21 W prowadzonym przez Ministerstwo Sprawiedliwości Federacji Rosyjskiej rejestrze organizacji pozarządowych pełniących funkcje agenta zagranicznego znajduje się rubryka 
szerokie możliwości interpretacyjne dla urzędników administracji państwowej i funkcjonariuszy resortów siłowych. Należy tu podkreślić, że pracowali oni w warunkach rywalizacji w manifestowaniu gorliwości i lojalności wobec przełożonych, co było szczególnie istotne w obliczu kryzysu ekonomicznego, redukcji kadr i przygotowań do przeprowadzenia wyborów ${ }^{22}$.

Akty prawne Federacji Rosyjskiej ${ }^{23}$ ograniczające prawa i wolności obywatelskie miały stanowić wzorzec dla podobnych rozwiązań w Uzbekistanie, Kazachstanie $^{24}$, Tadżykistanie ${ }^{25}$ i Kirgistanie ${ }^{26}$. W ostatnim z wymienionych państw parlamentarzyści Tursunbaj Bakir uulu, Nurkamil Madalijew oraz Nadira Narmatowa wystąpili 26 maja 2014 r. w Żogorku Kenesz z propozycją ograniczenia działalności organizacji pożytku publicznego w Kirgistanie. Sporządzony przez nich projekt ustawy o zmianie niektórych aktów prawnych Republiki Kirgiskiej zakładał nowelizację ustawy ' $O$ organizacjach niekomercyjnych', ustawy 'O państwowej rejestracji osób prawnych, a także ich oddziałów i przedstawicielstw' oraz kodeksu karnego. W myśl tej propozycji

dotycząca politycznych aspektów ich działalności. Na przykład, za działalność polityczną wprowadzonej do rejestru 23.06.2017 r. swierdłowskiej regionalnej fundacji publicznej projektów społecznych Nowy Czas uznano: zapobieganie społecznie istotnym chorobom w obwodzie swierdłowskim; apele do organów państwowych, organów samorządu lokalnego oraz do ich urzędników; upowszechnianie (także przy użyciu nowoczesnych technologii informacyjnych) opinii na temat decyzji podejmowanych przez organy państwowe i realizowanych przez nie polityk; wpływanie na opinię publiczną poprzez informowanie, gromadzenie i rozpowszechnianie informacji, prowadzenie badań opinii publicznej i publikowanie ich wyników; udział w organizacji dyskusji i wystąpień oraz ich prowadzenie. Szerzej zob. Sverdlovskij regional'nyj obsestvennyj fond social'nyh proektov ,, Novoe vremâ". Vidy političeskoj deâtel'nosti, „Ministerstvo ûsticii Rossijskoj Federacii” [online, dostęp: 3.01.2018], dostępny w internecie: $<$ http://unro.minjust.ru/NKOForeignAgent.aspx $>$.

22 K. Chawryło, M. Domańska, Obcy wśród swoich. Organizacje pozarzadowe w Rosji, 28.09.2015 (Komentarze OSW, 184).

23 Szerzej zob. N. Shukuralieva, Demokratičeskaâ samoorganizaciâ. Mobilizaciâ vo vremâ „,cvetnyh revolûcij”, „Studia Politologiczne” 2018, nr 48, s. 100-101.

24 S. Urnaliev, V Kazahstane gotovât svoj zakon „Ob inostrannyh agentah”, „Radio Azattyk" [online], 7.04.2015 [dostęp: 4.12.2015], dostępny w internecie: <https://rus.azattyq. org/a/zakon-ob-inostrannyh-agentah-v-kazakhstane/26941153.html>; V. Volkov, Kazahstan: gosudarstvo zajmetsâ NPO, „Deutsche Welle” [online], 12.11.2015 [dostęp: 15.03.2018], dostępny w internecie: <http://p.dw.com/p/1H45c>; A. Grishin, Dismay as NGO law goes through in Kazakstan, „Institute for War \& Peace Reporting” [online], 5.12.2015 [dostęp: 31.01.2016], dostępny w internecie: <https://iwpr.net/global-voices/ dismay-ngo-law-goes-through-kazakstan>.

25 NGO law brings chill wind to Tajikistan, „Institute for War \& Peace Reporting” [online], 25.11.2015 [dostęp: 31.01.2016], dostępny w internecie: <https://iwpr.net/global-voices/ ngo-law-brings-chill-wind-tajikistan>.

26 T. Gluškova, A. Pomeon, Kyrgyzstan na rasput'e: udastsâ li sohranit' prostranstvo dlâ pravozaŝitnoj deâtel'nosti? Doklad meždunarodnoj missii, FIDH 2016, s. 23-31. 
podmioty finansowane spoza kraju miały otrzymać status agenta zagranicznego, a ich działalność miała być poddana całkowitej kontroli organów państwowych.

Co ciekawe, implementacja rosyjskich rozwiązań do kirgiskiej rzeczywistości prezentowana była jako wyraz patriotyzmu. Autorzy proponowanych nowel twierdzili, że miały one powstrzymać zachodnich szpiegów i agentów działających pod płaszczykiem organizacji pozarządowych przed ingerowaniem w politykę wewnętrzną państwa. Bakir uulu mówił, że „Organizacje międzynarodowe piorą pieniądze w Kirgistanie i organizują kolorowe rewolucje na całym świecie". Wyraził również swoje niezadowolenie z faktu, że finansowane z zagranicy organizacje pozarządowe zajmujące się ochroną praw człowieka systematycznie wszczynają w kraju protesty (,Skąd oni biorą pieniądze na te protesty? Czy wiecie, ile pieniędzy potrzeba, aby zorganizować wiec?"') ${ }^{27}$. Nowe instrumenty prawne miały według Bakira uulu umożliwić pociągnięcie tych podmiotów „do odpowiedzialności, aby nie naruszały stabilności republiki, aby nie występowały przeciwko suwerenności państwa, aby szanowały wewnętrzny spokój w państwie"28.

Warto zaznaczyć, że proponowane rozwiązania nie spotkały się z entuzjastycznym przyjęciem ani władzy, ani społeczeństwa. Dystansował się od nich prezydent Kirgistanu Ałmazbek Atambajew, a krytyczne stanowisko zajął również minister sprawiedliwości Ałmambet Szykmamatow. Implementacja rosyjskiej ustawy 'O zagranicznych agentach' miała według niego ograniczać społeczeństwo otwarte oraz uderzać w organizacje pozarządowe, z których 80-90\% aktywnie współpracowało z państwem w rozwiązywaniu problemów społecznych oraz zapewnianiu ochrony praw człowieka ${ }^{29}$.

27 Oświadczenia Tursunbaja Bakira uulu na posiedzeniu frakcji parlamentarnej Ar-Namys 15.02.2013 r.: Deputat poručil finrazvedke vyâvit' istočniki finansirovaniâ NPO v Kirgizii, „FOR” [online], 15.02.2013 [dostęp: 15.03.2018], dostępny w internecie: <http://www. for.kg/news-214529-ru.html>.

28 A. Almazbekov, Interv'û: Bakir uulu rasskazal, za čto on ne lûbit NPO, „Kloop” [online], 27.09.2013 [dostęp: 15.03.2018], dostępny w internecie: <https://kloop.kg/ blog/2013/09/27/interv-yu-bakir-uulu-rasskazal-za-chto-on-ne-lyubit-npo/>; A. Âlovkina, Tursunbaj Bakir uulu: Meždunarodnye organizacii otmyvaût den'gi v Kyrgyzstane, „Večernij Biškek” [online], 15.02.2013 [dostęp: 15.03.2018], dostępny w internecie: $<$ https://www.vb.kg/doc/216517_tyrsynbay_bakir_yyly:_mejdynarodnye_organizacii otmyvaut_dengi_v_kyrgyzstane.html $>$.

29 NPO Kyrgyzstana razdelât na ,agentov” $i$,, čestnyh”, „Region” [online], 16.12.2014 [dostęp: 15.03.2018], dostępny w internecie: <http://www.region.kg/index.php?option= com_content\&view=article\&id=1263:----lr--lr\&catid=5:obshestvo\&Itemid=6>; A. Kutueva, U Minûsta Kyrgyzstana net vozmožnosti provodit' èkspertizu finansovoj deâtel'nosti nekommerčeskih organizacij, „24” [online], 26.06.2015 [dostęp: 15.03.2018], dostępny w internecie: $<$ https://24.kg/parlament/15145/>. 
Lokalni aktywiści wyrażali z kolei obawy przed wzmocnieniem zależności kraju od Rosji ${ }^{30}$.

Na poziomie międzynarodowym inicjatywa ustawodawcza kirgiskich posłów spotkała się jednak z silnym poparciem, i to nie tylko ze strony władz rosyjskich, ale i struktur integracyjnych. Sekretarz generalny Organizacji Układu o Bezpieczeństwie Zbiorowym (OUBZ) Nikołaj Bordiuża powiedział wiosną 2015 r. w wywiadzie dla kirgiskiej prasy, że finansowane z zagranicy organizacje pozarządowe wpływają na sytuację społeczno-polityczną w Kirgistanie, co zagraża bezpieczeństwu republiki. Podkreślił również, że OUBZ monitoruje te podmioty i ich działania. Kilka miesięcy później Żogorku Kenesz przyjął projekt ustawy w pierwszym czytaniu, bez przeprowadzenia dyskusji. Za przyjęciem nowego aktu prawnego opowiedziało się 83 deputowanych, a 23 było przeciw. Ostatecznie, po wielu zawirowaniach, w maju 2016 r. kirgiski parlament odrzucił projekt ustawy ${ }^{\circ} O$ organizacjach niekomercyjnych'. 65 ze 111 obecnych na posiedzeniu deputowanych zagłosowało przeciwko, uważając, że ograniczy ona prawa obywatelskie i doprowadzi do zmniejszenia pomocy międzynarodowej dla Kirgistanu ${ }^{31}$.

\section{Prewencja na poziomie kultury}

Prewencja kulturowa ma na celu wyeliminowanie z dyskursu publicznego alternatywnych wyobrażeń na temat zmian społeczno-politycznych. Rezultatem

30 Według Tolekan Ismailowej - znanej kirgiskiej działaczki na rzecz praw człowieka i szefowej fundacji Bir Dujno-Kirgistan - kirgiska wersja ustawy o zagranicznych agentach „została zainicjowana przez starą kirgiską nomenklaturę, która przed wyborami udaje się do Kremla po pieniądze. Oni nie chcą mieć nad sobą cywilnej kontroli i boją się startować w wyborach, gdyż nie mają poparcia elektoratu". Szerzej zob. Slova genseka ODKB o kontrole NPO v Kyrgyzstane - vmešatel'stvo v dela strany - Ismailova, „KirTAG” [online], 12.03.2015 [dostęp: 15.03.2018], dostępny w internecie: <https://www.kyrtag.kg/news/slova-genseka-odkb-o-kontrole-npo-v-kyrgyzstane-vmeshatelstvo-v-delastrany-ismailova-/>; Vyskazyvaniâ genseka ODKB pokazyvaût slabost' vlastej Kyrgyzstana - Aziza Abdirasulova, „KirTAG” [online], 13.03.2015 [dostęp: 15.03.2018], dostępny w internecie: <https://www.kyrtag.kg/news/vyskazyvaniya-genseka-odkb-pokazyvayut-slabost-vlastey-kyrgyzstana-aziza-abdirasulova>

31 Szerzej zob.: B. Asanov, „Tynčy” myjzamyn parlament koldogon žok, „Azattyk ùnalgysy" [online], 12.05.2016 [dostęp: 15.03.2018], dostępny w internecie: $<$ https://www. azattyk.org/a/kyrgyzstan ngo parlaiment law/27730911.html>; È. Bejšenbek kyzy, Bejôkmôt uûmdar ŽKKUnun kôz kyrynda, „Azattyk ùnalgysy” [online], 9.03.2015 [dostęp: 15.03.2018], dostępny w internecie: $<$ https://www.azattyk.org/a/kyrgyzstan_russia bordyuzha ngo /26889705.html>; U. Akišev, Zakon ob , inostrannyh agentah " prošel pervoe čtenie v parlamente, „Kloop” [online], 4.06.2015 [dostęp: 15.03.2018], dostępny w internecie: <https://kloop.kg/blog/2015/06/04/zakon-ob-inostrannyh-agentah-proshel-pervoe-chtenie-v-parlamente/>. 
manipulacji świadomością społeczną oraz pamięcią zbiorową ma być wzbudzenie strachu i awersji do samej idei innego urządzenia relacji na linii władza-społeczeństwo ${ }^{32}$. Szczególną wagę przykłada się do upowszechniania i utrwalania mitów dotyczących wewnętrznej opozycji politycznej, demokracji czy sprawiedliwości społecznej. Silicki zwraca uwagę, że antydemokratyczna prewencja kulturowa na obszarze postradzieckim prowadzona była w znacznej mierze pod hasłem zwalczania międzynarodowego terroryzmu. Przy wsparciu organów bezpieczeństwa Federacji Rosyjskiej budowano w świadomości tamtejszych społeczeństw skojarzenia między demokracją a terroryzmem, a rosyjskie prorządowe media zdecydowanie dyskredytowały demokratyzujące się państwa obszaru postradzieckiego w oczach odbiorców z całej WNP. Jedną z form prewencji kulturowej było też zaangażowanie rosyjskich spin doktorów w kampaniach propagandowych ${ }^{33}$.

W listopadzie 2014 r. kirgiskie państwowe kanały telewizyjne ElTR oraz OszTV wyemitowały reportaż pt. Konie trojańskie ${ }^{34}$. Widzowie dowiadywali się z niego, że priorytetem Stanów Zjednoczonych jest niszczenie kolejnych państw według ściśle określonego scenariusza. W fazie początkowej Waszyngton wysyła szpiegów i zakłada przy ich pomocy organizacje międzynarodowe oraz pozarządowe. Następnie w społeczeństwie promowane są i utrwalane wartości demokratyczne, np. wolność słowa czy wolność wyboru. Trzeci etap polega według autorów reportażu na promocji nietradycyjnej orientacji seksualnej, w następstwie czego dochodzi do upadku tradycyjnych wartości rodzinnych. Na koniec ,wychowani przez zachodnie organizacje pozarządowe $^{35 "}$ " przywódcy nieprzejednanej opozycji (opisywani jako homoseksualiści, pedofile, scjentolodzy) przyczyniają się do wybuchu protestów, kolorowych rewolucji czy nawet wojny domowej. Jak informował materiał:

\begin{abstract}
Wysłannicy demokracji w początkowej fazie badają sytuację wewnętrzną kraju przyjmującego. [...] Wydają miliony dolarów na takie projekty, jak obrona mniejszości seksualnych, suwerenność genderowa i tym podobne przedsięwzięcia. W Kirgistanie wedle danych Ministerstwa Sprawiedliwości zarejestrowanych było więcej niż 16000 organizacji pozarządowych. Departament Stanu USA corocznie przesyła do Kirgistanu
\end{abstract}

32 Zob. np. N. Shukuralieva, Demokratyczna rewolucja czy bunt mas? Konstruowanie pamięci oficjalnej w Kirgistanie w latach 2005-2010, „Studia Polityczne” 2011, nr 28, s. 113-132.

33 V. Silitski, Contagion..., s. 33.

34 Troânskie koni, „You Tube” [online], 2014 [dostęp: 15.03.2018] dostępny w internecie: $<$ https://www.youtube.com/watch?time_continue $=6 \& \mathrm{v}=$ epQgLHM-AJ4 $>$.

35 Tamże. 
miliony dolarów za pośrednictwem swoich organizacji pod postacią grantów. Działając na zlecenie swoich zachodnich mecenasów, pozarządowe organizacje obrońców praw człowieka promują najczęściej takie projekty, jak wolność słowa, wolność wyboru itd. Kiedy społeczeństwo nasyci się tymi wolnościami, przyzwyczaja się do nich, wówczas następuje kolejny etap, prowadzony przez te same organizacje obrońców praw człowieka. Zaczynają oni propagować tolerancję wobec takich rzeczy, jak nietradycyjne orientacje seksualne, które zawsze były traktowane jako haniebne i niszczące tradycyjne wartości rodzinne. Ten etap trwa właśnie w Kirgistanie, dzięki określonym osobom oraz organizacjom pozarządowym, które w ten sposób chcą rozbić nasze społeczeństwo ${ }^{36}$.

Dyskredytacja organizacji czy poszczególnych osób, które angażowały się $\mathrm{w}$ walkę o grupowe interesy obywateli oraz wspieranie solidarności i świadomości obywatelskiej w Kirgistanie, postępowała równolegle z inicjatywami implementacji rosyjskich projektów prawnych, takich jak wspomniane ustawy o zagranicznych agentach, niepożądanych organizacjach czy zakazie propagandy homoseksualizmu wśród nieletnich. Przekazy medialne czy wystąpienia osób publicznych w rozmaitych gremiach opierały się głównie na idei konserwatywnej, wykorzystywanej przez Moskwę do promocji postaw prorosyjskich ${ }^{37}$. Składają się na nią tradycyjne wartości patriarchalne, patriotyzm państwowy, ideologiczny antyokcydentalizm, sięgające do filozoficznych założeń rosyjskich słowianofilów, antyliberalizmu i prawosławia. Materiały dyskredytujące działaczy trzeciego sektora skierowane do odbiorcy w Kirgistanie musiały jednak nieco odbiegać od tych, które prezentowano Rosjanom. Wpływanie na społeczeństwo w postkolonialnym, peryferyjnym kraju, w którym dominuje islam, a organizacje pozarządowe wykazują się dużą aktywnością, wymagało wykorzystania odmiennych treści - zastąpienia rywalizacji Rosji z Zachodem wewnętrznymi lękami państw Azji Centralnej. Zrezygnowano zatem w tym przypadku z eksponowania rosyjskiej unikalności religijnej, kulturowej i cywilizacyjnej oraz moralnej wyższości nad zdegenerowanym Zachodem, pozostawiając jednak w przekazie dychotomię między Wschodem a Zachodem. W myśl tych narracji kulturowych zachodnie wartości zagrażały nie Rosji, ale na przykład Kirgistanowi. Modyfikacja akcentów pozwalała korzystać z geopolitycznych koncepcji rosyjskich służb

36 Tamże.

37 J. Doroszczyk, Antyzachodnie think tanki w Rosji jako narzędzie realizacji konserwatywnego projektu Kremla, „Sprawy Międzynarodowe” 2016, nr 3, s. 118-129. 
specjalnych $^{38}$, jak gdyby były one rodzimie kirgiskie. W ten sposób do rzeczywistości społeczno-politycznej tego kraju wróciła dobrze znana z czasów zimnej wojny klisza wrogiego i zepsutego Zachodu.

\section{Zakończenie}

Celem niniejszego tekstu było przedstawienie zjawiska integracji obronnej państw Azji Centralnej z uwzględnieniem szerszego kontekstu międzynarodowego oraz roli Wspólnoty Niepodległych Państw i Szanghajskiej Organizacji Współpracy. Umożliwia ona socjalizowanym jeszcze w czasach radzieckich autorytarnym przywódcom obniżenie kosztów utrzymywania reżimów politycznych, ponieważ wymyślone w jednym kraju strategie, rozwiązania instytucjonalno-prawne czy konstrukty mitologiczne wykorzystywane są przez innych członków tych organizacji. Obie zapewniają na dodatek międzynarodową infrastrukturę, która daje reżimom zewnętrzną legitymizację, i służą osłabieniu społeczeństwa obywatelskiego oraz eliminowaniu politycznej konkurencji.

Realizowane przez te instytucje strategie kreują w świadomości społecznej czarno-białą, konfrontacyjną wizję świata. Omawiane przykłady pokazują, jak promocja praw i swobód obywatelskich oraz metod ich obrony prezentowane były jako instrument destabilizacji politycznej i destrukcji potencjału państw regionu. Można tu mówić o wspólnym autorytarnym software obszaru postradzieckiego, który w procesie integracji i wzajemnego uczenia się daje się szybko aktualizować. Stworzenie wspólnej bazy danych (dotyczących taktyk, instytucji oraz kultury) umożliwiło z kolei monitorowanie bieżących wyzwań oraz wdrażanie najnowocześniejszych rozwiązań zapewniających stabilność systemów autorytarnych.

\section{Bibliografia}

Akišev U., Zakon ob „inostrannyh agentah” prošel pervoe čtenie v parlamente, „Kloop” [online], 4.06.2015 [dostęp: 15.03.2018], dostępny w internecie: <https://kloop.kg/ blog/2015/06/04/zakon-ob-inostrannyh-agentah-proshel-pervoe-chtenie-v-parlamente/>.

Allison R., Virtual regionalism, regional structures and regime security in Central Asia, „Central Asian Survey” 2008, nr 2 (27).

Almazbekov A., Interv'û: Bakir uulu rasskazal, za čto on ne lûbit NPO, „Kloop” [online], 27.09.2013 [dostęp: 15.03.2018], dostępny w internecie: <https://kloop.kg/blog/ 2013/09/27/interv-yu-bakir-uulu-rasskazal-za-chto-on-ne-lyubit-npo/>.

38 Taż, Geopolityka rosyjskich specsłużb - wpływ środowiska siłowego na ideę imperialnej Rosji, „Przegląd Geopolityczny” 2017, nr 21, s. 101-116. 
Âlovkina A., Tursunbaj Bakir uulu: Meždunarodnye organizacii otmyvaût den'gi v Kyrgyzstane, „Večernij Biškek” [online], 15.02.2013 [dostęp: 15.03.2018], dostępny w internecie: $<$ https://www.vb.kg/doc/216517_tyrsynbay_bakir_yyly:_mejdynarodnye_organizacii_ otmyvaut_dengi_v_kyrgyzstane.html $>$.

Asanov B., „Tyņ̌y”” myjzamyn parlament koldogon žok, „Azattyk ùnalgysy” [online], 12.05.2016 [dostęp: 15.03.2018], dostępny w internecie: <https://www.azattyk.org/a/kyrgyzstan_ngo_parlaiment_law/27730911.html>.

Azja Centralna. Tożsamość, naród, polityka, red. N. Shukuralieva, Nomos, Kraków 2018.

Bejšenbek kyzy Ė., Bejôkmôt uûmdar ŽKKUnun kôz kyrynda, „Azattyk ùnalgysy” [online], 9.03.2015 [dostęp: 15.03.2018], dostępny w internecie: $<$ https://www.azattyk.org/a/kyrgyzstan_russia_bordyuzha_ngo_/26889705.html >.

Bezpieczeństwo Europy. Aspekty geopolityczne, red. T.Z. Leszczyński, Polskie Towarzystwo Geopolityczne, Kraków 2015.

Brążkiewicz D., Śliwa Z., Strategiczne interesy Rosji w Azji Centralnej, „Kwartalnik Bellona” 2011, nr 4 (667).

Chawryło K., Domańska M., Obcy wśród swoich. Organizacje pozarządowe w Rosji, 28.09.2015 (Komentarze OSW, 184).

Cooley A.A., Heathershaw J., Dictators without borders. Power and money in Central Asia, Yale University Press 2017.

Deputat poručil finrazvedke vyâvit' istočniki finansirovaniâ NPO v Kirgizii, „FOR” [online], 15.02.2013 [dostęp: 15.03.2018], dostępny w internecie: $<$ http://www.for.kg/news214529-ru.html>.

Doroszczyk J., Antyzachodnie think tanki w Rosji jako narzędzie realizacji konserwatywnego projektu Kremla, „Sprawy Międzynarodowe” 2016, nr 3.

Doroszczyk J., Geopolityka rosyjskich specslużb - wplyw środowiska siłowego na ideę imperialnej Rosji, „Przegląd Geopolityczny” 2017, nr 21.

Fel'dman D., Političeskoe vzaimodejstvie èlit stran SNG, „Polis. Političeskie issledovaniâ” 2005, nr 4.

FSB i dviženiâ Central'noj Azii: analiz, „Agentura” [online], 18.04.2007 [dostęp: 15.03.2018], dostępny w internecie: $<\mathrm{http}: / /$ www.agentura.ru/experts/ponomarev/>.

Gluškova T., Pomeon A., Kyrgyzstan na rasput'e: udastsâ li sohranit' prostranstvo dlâ pravozaŝitnoj deâtel'nosti? Doklad meždunarodnoj missii, FIDH 2016.

Grishin A., Dismay as NGO law goes through in Kazakstan, „Institute for War \& Peace Reporting” [online], 5.12.2015 [dostęp: 31.01.2016], dostępny w internecie: <https:// iwpr.net/global-voices/dismay-ngo-law-goes-through-kazakstan>.

Heathershaw J., Megoran N., Contesting danger. A new agenda for policy and scholarship on Central Asia, „International Affairs” 2011, nr 3 (87).

Heathershaw J., Montgomery D.W., The myth of post-Soviet Muslim radicalization in the Central Asian republics, Chatham House 2014.

Jackson N.J., The role of external factors in advancing non-liberal democratic forms of political rule. A case study of Russia's influence on Central Asian regimes, „Contemporary Politics" 2010, vol. 16, No. 1.

Konvenciâ o pravovoj pomoŝi i pravovyh otnošeniâh po graždanskim, semejnym i ugolovnym delam, Minsk 22.01.1993.

Konvenciâ Šanhajskoj organizacii sotrudničestva protiv terrorizma, Ekaterinburg 16.06.2009. 
Kutueva A., U Minûsta Kyrgyzstana net vozmožnosti provodit' èkspertizu finansovoj deâtel'nosti nekommerčeskih organizacij, „24” [online], 26.06.2015 [dostęp: 15.03.2018], dostępny w internecie: <https://24.kg/parlament/15145/>.

Legucka A., System bezpieczeństwa obszaru poradzieckiego tworzony wokót OUBZ, [w:] Bezpieczeństwo Europy. Aspekty geopolityczne, red. T.Z. Leszczyński, Polskie Towarzystwo Geopolityczne, Kraków 2015.

Libman A., Modeli èkonomičeskoj integracii. Mirovoj i postsovetskij opyt, IE RAS, Moskva 2009. Meždunarodnye nablûdateli - partnery po razvitiû demokratii, a ne sud'i, ,Sankt-Peterburgskie vedomosti”, 10.02.2016.

NGO law brings chill wind to Tajikistan, „Institute for War \& Peace Reporting” [online], 25.11.2015 [dostęp: 31.01.2016], dostępny w internecie: <https://iwpr.net/global-voices/ ngo-law-brings-chill-wind-tajikistan>.

NPO Kyrgyzstana razdelât na ,agentov” $i$,čestnyh”, „Region” [online], 16.12.2014 [dostęp: 15.03.2018], dostępny w internecie: $<$ http://www.region.kg/index.php?option=com content\&view=article \&id=1263:----1r--1r\&catid=5:obshestvo\&Itemid=6>.

Ob informacionnyh učetah Regional'noj antiterrorističeskoj organizacii Šanhajskoj organizacii sotrudničestva, „Regional'naâ Antiterrorističeskaâ Struktura Šanhajskoj Organizacii Sotrudničestva" [online], 28.07.2017 [dostęp: 15.03.2018], dostępny w internecie: <http:// ecrats.org/ru/news/6914>.

PIVT vnesli v perečen' terrorističeskih organizacij RATS ŠOS, „EurAsia Daily” [online], 4.08.2017 [dostęp: 15.03.2018], dostępny w internecie: <eadaily.com/ru/news/2017/08/04/ pivt-vnesli-v-perechen-terroristicheskih-organizaciy-rats-shos>.

Položenie o Meždunarodnom institute monitoringa razvitiâ demokratii, parlamentarizma i soblûdeniâ izbiratel'nyh prav graždan gosudarstv - učastnikov MPA SNG [postanowienie Rady Międzyparlamentarnego Zgromadzenia WNP z 10.02.2006 r. nr 5].

Procesy integracyjne $i$ dezintegracyjne na obszarze poradzieckim. Próba bilansu, red. T. Ambroziak, A. Czwołek, S. Gajewski, M. Nowak-Paralusz, Wydawnictwo „Adam Marszałek", Toruń 2015.

Relacje Unii Europejskiej z Azja Centralna. Uwarunkowania, wyzwania, efekty, red. T. Wallas, R. Fiedler, Poznań 2018.

Sarkorova A., V Tadžikistane zapreŝena Islamskaâ partiâ, „BBC Russkaâ služba” [online], 29.09.2015 [dostęp: 15.03.2018], dostępny w internecie: <http://www.bbc.com/russian/ international/2015/09/150929_tajikistan_islamic_party_ban>.

Shukuralieva N., Azja Centralna: uwarunkowania integracji regionalnej, [w:] Relacje Unii Europejskiej z Azja Centralną. Uwarunkowania, wyzwania, efekty, red. T. Wallas, R. Fiedler, Poznań 2018.

Shukuralieva N., Bezpieczeństwo międzynarodowe, terroryzm i zasoby naturalne a międzynarodowa legitymizacja władzy w krajach Azji Środkowej, ,Sprawy Międzynarodowe” 2013, nr 4.

Shukuralieva N., Demokratičeskaâ samoorganizaciâ. Mobilizaciâ vo vremâ , cvetnyh revolûcij”, „Studia Politologiczne” 2018, nr 48.

Shukuralieva N., Demokratyczna rewolucja czy bunt mas? Konstruowanie pamięci oficjalnej w Kirgistanie w latach 2005-2010, „Studia Polityczne” 2011, nr 28.

Shukuralieva N., Lipiński A., Legitymizacja władzy jako wielowymiarowy mechanizm stabilizacji systemu autorytarnego. Casus państw Azji Centralnej, [w:] Azja Centralna. Tożsamość, naród, polityka, red. N. Shukuralieva, Nomos, Kraków 2018. 
Shukuralieva N., Lipiński A., Uwarunkowania legitymizacji władzy w systemach autorytarnych. Casus państw Azji Centralnej, „Przegląd Politologiczny” 2017, nr 1.

Silitski V., Contagion deterred: preemptive authoritarianism in the former Soviet Union (the case of Belarus), Stanford 2006 (CDDRL Working Papers, 66).

Slova genseka ODKB o kontrole NPO v Kyrgyzstane - vmešatel'stvo v dela strany - Ismailova, „KirTAG” [online], 12.03.2015 [dostęp: 15.03.2018], dostępny w internecie: <https://www. kyrtag.kg/news/slova-genseka-odkb-o-kontrole-npo-v-kyrgyzstane-vmeshatelstvo-v-delastrany-ismailova-/>.

Sverdlovskij regional'nyj obŝestvennyj fond social'ny h proektov „, Novoe vremâ”. Vidy političeskoj deâtel'nosti, „Ministerstvo ûsticii Rossijskoj Federacii” [online, dostęp: 3.01.2018], dostępny w internecie: $<$ http://unro.minjust.ru/NKOForeignAgent.aspx $>$.

Troânskie koni, ,YYou Tube” [online], 2014 [dostęp: 15.03.2018] dostępny w internecie: <https:// www.youtube.com/watch?time_continue $=6 \& \mathrm{v}=\mathrm{epQgLHM}-\mathrm{AJ} 4>$.

Urnaliev S., V Kazahstane gotovât svoj zakon „Ob inostrannyh agentah”, „Radio Azattyk” [online], 7.04.2015 [dostęp: 4.12.2015], dostępny w internecie: <https://rus.azattyq.org/a/zakon-ob-inostrannyh-agentah-v-kazakhstane/26941153.html $>$.

Volkov V., K čemu PIVT vynuždaût repressii so storony tadžikskih vlastej?, „Deutsche Welle" [online], 28.09.2016 [dostęp: 15.03.2018], dostępny w internecie: <http://p.dw. $\mathrm{com} / \mathrm{p} / 1 \mathrm{~K} 752>$.

Volkov V., Kazahstan: gosudarstvo zajmetsâ NPO, „Deutsche Welle” [online], 12.11.2015 [dostęp: 15.03.2018], dostępny w internecie: $<\mathrm{http}: / / \mathrm{p} . \mathrm{dw} . \mathrm{com} / \mathrm{p} / 1 \mathrm{H} 45 \mathrm{c}>$.

Vyskazyvaniâ genseka ODKB pokazyvaût slabost' vlastej Kyrgyzstana - Aziza Abdirasulova, „KirTAG” [online], 13.03.2015 [dostęp: 15.03.2018], dostępny w internecie: <https://www. kyrtag.kg/news/vyskazyvaniya-genseka-odkb-pokazyvayut-slabost-vlastey-kyrgyzstanaaziza-abdirasulova>.

Żęgota K., Kreowanie rzeczywistości alternatywnej. Dążenia integracyjne Rosji w przestrzeni poradzieckiej, [w:] Procesy integracyjne i dezintegracyjne na obszarze poradzieckim. Próba bilansu, red. T. Ambroziak, A. Czwołek, S. Gajewski, M. Nowak-Paralusz, Wydawnictwo „Adam Marszałek”, Torun 2015. 